\title{
LONG TERM EFFICACY AND SAFETY OF ADALIMUMAB IN JUVENILE IDIOPATHIC ARTHRITIS (JIA) ASSOCIATED UVEITIS
}

\author{
Dragana Lazarević1,2, Marija Ratković Janković2, Milica Jakovljević2, Jelena Vojinović1,2
}

In the last decade, tumor necrosis factor- $\alpha$ (TNF- $\alpha$ ) inhibitors have shown excellent control of ocular inflammation in juvenile idiopathic arthritis (JIA)-associated uveitis. We have retrospectively evaluated the long-term efficacy and safety of adalimumab in 19 biologically naive patients with JIA-associated uveitis from our biologic registry. Demographic data and blood samples were collected at different time points. Uveitis activity was evaluated by slit-lamp biomicroscopy. Adverse events were recorded.

The registry records provided a ten-year follow-up of 11 (57.90\%) female patients diagnosed with oligo/extended oligoarticular JIA-associated uveitis and $8(42.10 \%)$ males diagnosed with enthesitis-related arthritis (ERA) with uveitis. Adalimumab was the first biologic prescribed to JIA patients with active uveitis that failed to respond to standard treatment. A ten- year long follow-up period has shown that there were no new relapsis of uveitis while patients were receiving adalimumab and metotrexate. All of our patients after adalimumab introduction were able to gradually tapper and stop treatment with topical steroids. Thirty-six point eighty-four percent of our patients were able to stop biological treatment 36 months after adalimumab commencing. Uveitis has relapsed three monts after the adalimumab discontinuation only in two patients (10.53\%). No serious adverse events were recorded. Thirty-one point fifty-eight percent of patients expirienced minor adverse events.

During a long-term follow-up, adalimumab showed good efficacy and safety profile in JIA patients with active inflammatory ocular disease.

Acta Medica Medianae 2021;60(3):30-36.

Key words: juvenile idiopathic arthritis, uveitis, adalimumab

${ }^{1}$ University of Niš, Faculty of Medicine, Niš, Serbia

2University Clinical Center Niš, Clinic of Pediatrics, Department of Pediatric Rheumatology, Niš, Serbia

Contact: Dragana Lazarević

48 Dr Zoran Djindjić Blvd., 18000 Niš, Serbia

E-mail: lazarevic.gaga@gmail.com

\section{Introduction}

Juvenile idiopatic arthritis (JIA) is one of the most common reumatic diseases in children $(1,2)$ with uveitis as the most severe extra-articular JIA manifestation, more frequently in some JIA disease subtypes $(3,4)$. Uveitis is usually asymptomatic and could be diagnosed very late when ocular damage is already present (5). Delayed diagnosis and inade- quate uveitis treatment can lead to the serious structural changes and visual loss with huge impact on everyday quality of life. Regular disease activity monitoring, ophtalmological screening and standardized treatment are obligatory in order to prevent visual loss in these patients $(4,6-11)$.

In the last decade, the advent of tumor necrosis factor (TNF) blockers have changed the treatment recommedations and disease course in patients who failed to respond to conventional topical and second-line disease modifying antirheumatic drugs (DMARDS) (12). Of the TNF- $\alpha$ inhibitors, infliximab and adalimumab are shown to be the most effective in controlling persistent ocular inflammation (13-16). Diverse studies have confirmed a favourable uveitis outcome and safety profile in those treated with adalimumab compared with infliximab $(3,5,13,17-19)$. Etanercept has not been recommended in patients with uveitis as some data indicate that it can cause relaps of uveitis or induce uveitis "de novo" (20-24).

The main aim of our study was to evaluate retrospectively the long-term efficacy and safety of adalimumab in biologically naive JIA-associated uveitis patients. 


\section{Materials and methods}

We have retrospectively analysed 19 biologically naive JIA-associated uveitis patients' data (aged 4 to 18 years) from our biological registry (Clinic of Pediatrics, Clinical Center Niš) treated with biologic therapy between April 2010 to December 2020. All patients were diagnosed with oligo/extended oligoarticular and enthesitis-related arthritis JIA subtypes with uveitis, according to the JIA International League of Association for Rheumatology (ILAR) classification criteria (1). Adalimumab was the first biologic prescribed $\left(24 \mathrm{mg} / \mathrm{m}^{2}\right.$ in two weeks intervals) to all patients who failed to respond to conventional topical treatment with steroids and cycloplegics combined with DMARDS therapy (Metotrexate $10-20 \mathrm{mg} / \mathrm{m}^{2} /$ weekly), according to the treatment recommendations $(4,6,8)$. Demographic JIA-associated uveitis data such as sex, age at uveitis onset, uveitis duration, age at start with biologics and the previous and concomitant therapy, uveitis activity, treatment course, visual outcomes, ocular complications and adverse events were sistematically collected. Evaluation of the ocular activity was done by oftalmologist by slit-lamp biomicroscopy examination in concordance with actual recommendations $(6,7)$. Possibile complications of chronic inflammation were assessed by the measurement of intraocular pressure as well as fundus examination. Blood samples for routine laboratory monitoring and drug safety were collected every three months.

The study was approved by the local Ethics Committee and informed consent was assigned by parents and/or patients. The study was conducted in accordance with the principles of the Declaration of Helsinki.

\section{Statitical analysis}

Statitical analysis was performed using the standard statistical function in SPSS 18. All results are reported as the mean \pm standard error, minimal and maximal values.

\section{Results}

In this study, we report the ten-year followup data on efficacy and safety of adalimumab usage as the first prescribed biologic for the treatment of 19 biologically naive JIA associated uveitis patients refractory to the standard treatment. Eleven patients (57.90\%) were females diagnosed with oligo/ extended oligoarticular JIA, while eight (42.10\%) were males diagnosed with enthesitis-related arthritis (ERA). Detailed demographic and disease data are given in Table 1 . Before adalimumab was prescribed, the mean uveitis duration was 10 months and all patients were previously treated with metotrexate during 37 months, with an average dose of $10 \mathrm{mg} / \mathrm{m}^{2}$ per week. During the ten-year follow-up of adalimumab treatment, there were no new relapsis of uveitis and ocular inflammation was in stabile state. All of our patients were able to gradually tapper and stop treatment with topical steroids two months after adalimumab was commenced. Seven patients (36.84\%) were able to stop the biological treatment after 36 months of adalimumab use. Uveitis relapsed three monts after the adalimumab discontinuation only in two patients (10.53\%).

During the ten-year follow-up, we observed eight new ocular complications (Table 2). Cataract was the most commonly reported complication (26.31\%) followed by synechiae $(15.79 \%)$ and glaucoma (5.26\%). Four JIA-assocated uveitis patients with cataract were successfully operated. At the end of the follow-up, only two patients (10.53\%) had monocular visual loss which was already present before adalimumab was introduced.

As shown in Table 3, six patients (31.58\%) expirienced 10 minor adverse events. Three of our patients had multiple adverse events. Infections of urinary, respiratory and gastrointestinal tract $(36.84 \%)$, pain at the injection site $(10.52 \%)$, and local skin reaction $(5.26 \%)$ were the most frequently reported minor adverse events. We recorded no serious adverse events related to adalimumab.

Table 1. Demographic data of JIA associated uveitis patients $(n=19)$

\begin{tabular}{||l|c|c|c||}
\hline \multicolumn{1}{|c|}{ CHARACTERISTICS } & N (\%) & Mean \pm SD & Min.-Max. \\
\hline \hline Oligoarticular/extended oligoarticular JIA & $11 / 1(57.90)$ & & \\
\hline Enthesitis related JIA & $8 / 19(42.10)$ & & $3-43$ \\
\hline $\begin{array}{l}\text { Mean uveitis duration before inducing adalimumab, } \\
\text { months }\end{array}$ & & $37.42 \pm 33.58$ & $10-144$ \\
\hline $\begin{array}{l}\text { Average duration of methotrexate therapy before } \\
\text { inducing adalimumab, months }\end{array}$ & $10 \mathrm{mg} / \mathrm{m}^{2} /$ weekly & & \\
\hline Average dose of methotrexate & $0 / 19(0)$ & $2 \pm 0.88$ & $1-4$ \\
\hline $\begin{array}{l}\text { Uveitis relaps during adalimumab and MTX treatment } \\
\text { adalimumab introduction, months }\end{array}$ & & $36.10 \pm 24.53$ & $12-108$ \\
\hline $\begin{array}{l}\text { Cessation of adalimumab treatment due to remission, } \\
\text { months }\end{array}$ & $7 / 19(36.84)$ & & \\
\hline Uveitis relapsed after adalimumab discontinuation & $2 / 19(10.52)$ & & \\
\hline
\end{tabular}

SD - Standard deviation, Min - Minimum, Max- Maximum, JIA- Juvenile idiopathic Arthritis 
Table 2. Ocular complications of JIA associated uveitis patients during a ten-year long follow up

\begin{tabular}{|c|c||}
\hline Ocular complications & N (\%) \\
\hline \hline Cataract & $5 / 19(26.31)$ \\
\hline Synechiae & $3 / 19(15.79)$ \\
\hline Glaucoma & $1 / 19(5.26)$ \\
\hline
\end{tabular}

Table 3. Adverse events of JIA associated uveitis patients during a ten-year long follow up

\begin{tabular}{|c|c||}
\hline \multicolumn{1}{|c|}{ Adverse events } & N (\%) \\
\hline \hline Serious adverse events & $0 / 19$ \\
\hline Minor adverse events & $6 / 19(31.58)$ \\
\hline Infections & $7 / 19(36.84)$ \\
\hline Upper respiratory tract infection & $4 / 19(21.05)$ \\
\hline Urinary tract infection & $2 / 19(10.52)$ \\
\hline Gastrointestinal infection & $1 / 19(5,26)$ \\
\hline Pain at the injection site & $2 / 19(10.52)$ \\
\hline Local skin reactions & $1 / 19(5,26)$ \\
\hline
\end{tabular}

\section{Discussion}

Juvenile idiopathic arthritis (JIA)-associated uveitis is the most serious extra-articular manifestation of JIA and represents a treatment challenge for pediatric rheumatologist and ophtalmologist. Uncontrolled ocular inflammation could lead to severe structural changes with serious imparement of visual activity (25-27). Therefore, regular ophtalmological screening and disease activity assessment are esential in order to start treatment early before the permanent structural damage is done. In the last years, new treatment and folow-up recommendations have been established $(4,8,10,11,27-30)$. The inovation of anti-TNF- $\alpha$ drugs have changed uveitis disease course, long-term outcome and related complications in patients who did not respond to the second-line agents. Of the TNF- $\alpha$ inhibitors, adalimumab has shown to be the most effective in refractory cases of intraocular inflammation when used as the first biologic (3, 12, 28, 31-33).

In our study, we confirmed that adalimumab in combination with metotrexate had a good cilinical response in ocular inflammatory process and mantained a stabile disease course during the long-term follow-up period. In this study, the therapeutical bias showed no new flares and new worsnening of visual activity. Only two patients had monoocular visual loss, but it was present before starting adalimumab. Different authors have confirmed the same findings $(12,34,35)$. SYCAMORE and ADJUVITE trials have confirmed the strongest level of efficacy of adalimumab in combination with metotrexate in the control of ocular inflammation and significantly have improved evidence-based treatment of paediatric non-infectious uveitis $(33,36,37)$. Of importance is also that this dual treatment option has confirmed steroid sparing effects. Our patients were able to slowly reduce and finally stop steroids in short time period after commencing adalimumab and metotrexate. Thus, possibile serious consequences of long-term use of steroids on the growing up children and ocular adverse events from local treatments were prevented. This finding is in accordance with CARRA consensus treatment strategies for childhood acute uveitis (38) and an update of evidence-based treatment guidelines of JIA-associated uveitis (30, 39). Early start with systemic immunosuppression and corticosteroid discontinuation are crucial to prevent serious structural complications and need for ophtalmological surgery (40). Recent studies have confirmed that ocular complications in JIA uveitis are less freqent compared with previous ones $(29,41)$. Cataract, synehiae and glaucoma were the most commonly reported visual complications in our study group, which is in line with already published data $(15,19,27)$. Of note is to highlight the fact that all of our patients were previously biologically naive and similar findings have been already published by other authors, suggesting a better efficacy of adalimumab when used as a first anti-TNF- $\alpha$ treatment in chronic childhood uveitis $(13,42)$. However, there are still no evidence-based data when to stop biologics once the remission is achieved. The recommendations suggest to continue with immunosupresive treatment 18 to 24 months once uveitis has become inactive $(29,40) .36 .84 \%$ of our patients were able to stop biological treatment after 36 months, which is in contrast to the results of Acharya et al. where $68 \%$ of patients were unable to discontinue immunosupressive drugs (43). During the five-years follow-up of Bristol participants in SYNCAMORE trial, drug-induced remission was not persistant when adalimumab was withdrawn (44). 
In our study, two patients had a relapse of uveitis three monts after adalimumab was discontinued, which has been already published by Castiblanco et al. (45). The ongoing ADJUST trial will give answers in the near future on accessing efficacy after adalimumab discontinuing in patients with controlled JIAassociated uveitis (46). During the long-term followup, no serious adverse events were recorded, which points to the high safety profile of this therapeutical option. Only minor adverse events were reported.

\section{Conclusion}

JIA-associated uveitis still remains a treatment challenge for pediatric rheumatologis and ophtalmologist. The advent of biologics in the last decade has significantly improved the outcome of JIA-associated uveitis. The long-term follow-up data from our biological registry have confirmed effectiveness and safety of adalimumab used as a first biologic for the treatment of refractory JIA-associated uveitis.

\section{Conflict of interest}

The authors declare no conflict of interest.
1. Petty RE, Southwood TR, Manners P, Baum J, Glass DN, Goldenberg J, et al. International League of Associations for Rheumatology classification of juvenile idiopathic arthritis: second revision. J Rheumatol 2004;31(2):390-2.[PubMed]

2. Wells JM, Smith JR. Uveitis in juvenile idiopathic arthritis: recent therapeutic advances. Ophthalmic Res 2015;54(3):124-7. [CrossRef] [PubMed]

3. Kotaniemi K, Saila H, Kautiainen H. Long-term efficacy of adalimumab in the treatment of uveitis associated with juvenile idiopathic arthritis. Clin Ophthalmol 2011;5:1425-9. [CrossRef] [PubMed]

4. Bou R, Adan A, Borras F, Bravo B, Calvo I, De Inocencio $\mathrm{J}$, et al. Clinical management algorithm of uveitis associated with juvenile idiopathic arthritis: interdisciplinary panel consensus. Rheumatol Int 2015;35(5):777-85. [CrossRef] [PubMed]

5. Clarke SL, Sen ES, Ramanan AV. Juvenile idiopathic arthritis-associated uveitis. Pediatr Rheumatol Online J 2016;14(1):27. [CrossRef] [PubMed]
6. Angeles-Han ST, Ringold S, Beukelman T, Lovell D, Cuello CA, Becker ML, et al. 2019 American College of Rheumatology/Arthritis Foundation Guideline fo the Screening, Monitoring, and Treatment of Juvenile Idiopathic Arthritis-Associated Uveitis. Arthritis Rheumatol 2019;71(6):864-77. [CrossRef] [PubMed]

7. Jabs DA, Nussenblatt RB, Rosenbaum JT. Standardization of uveitis nomenclature for reporting clinical data. Results of the First International Workshop. Am J Ophthalmol 2005;140(3):509-16. [CrossRef] [PubMed]

8. Heiligenhaus A, Michels $H$, Schumacher C, Kopp I, Neudorf $U$, Niehues $T$, et al. Evidence-based, interdisciplinary guidelines for anti-inflammatory treatment of uveitis associated with juvenile idiopathic arthritis. Rheumatol Int 2012;32(5):1121-33. [CrossRef] [PubMed]

9. Bou R, Iglesias $\mathrm{E}$, Anton J. Treatment of uveitis associated with juvenile idiopathic arthritis. Curr Rheumatol Rep 2014;16(8):437. [CrossRef] [PubMed] 
10. Constantin T, Foeldvari I, Anton J, de Boer J, CzitromGuillaume S, Edelsten C, et al. Consensus-based recommendations for the management of uveitis associated with juvenile idiopathic arthritis: the SHARE initiative. Ann Rheum Dis 2018;77(8):1107-17. [CrossRef] [PubMed]

11. Angeles-Han ST, Ringold S, Beukelman T, Lovell D, Cuello CA, Becker ML, et al. 2019 American College of Rheumatology/Arthritis Foundation Guideline for the Screening, Monitoring, and Treatment of Juvenile Idiopathic Arthritis-Associated Uveitis. Arthritis Care Res 2019;71(6):703-16. [CrossRef] [PubMed]

12. Magli A, Forte R, Navarro P, Russo G, Orlando F, Latanza $L$, et al. Adalimumab for juvenile idiopathic arthritis-associated uveitis. Graefes Arch Clin Exp Ophthalmol 2013;251(6):1601-6. [CrossRef] [PubMed]

13. Simonini G, Taddio A, Cattalini M, Caputo R, de Libero C, Parentin F, et al. Superior efficacy of Adalimumab in treating childhood refractory chronic uveitis when used as first biologic modifier drug: Adalimumab as starting anti-TNF-alpha therapy in childhood chronic uveitis. Pediatr Rheumatol Online ] 2013;11:16. [CrossRef] [PubMed]

14. Simonini G, Druce K, Cimaz R, Macfarlane GJ, Jones GT. Current evidence of anti-tumor necrosis factor a treatment efficacy in childhood chronic uveitis: a systematic review and meta-analysis approach of individual drugs. Arthritis Care Res 2014;66(7):107384. [CrossRef] [PubMed]

15. Chan NS, Choi J, Cheung CMG. Pediatric Uveitis. Asia Pac J Ophthalmol 2018;7(3):192-9. [CrossRef] [PubMed]

16. Foeldvari I, Becker I, Horneff G. Uveitis Events During Adalimumab, Etanercept, and Methotrexate Therapy in Juvenile Idiopathic Arthritis: Data From the Biologics in Pediatric Rheumatology Registry. Arthritis Care Res 2015;67(11):1529-35. [CrossRef] [PubMed]

17. La Torre F, Cattalini M, Teruzzi B, Meini A, Moramarco $F$, Iannone $F$. Efficacy of adalimumab in young children with juvenile idiopathic arthritis and chronic uveitis: a case series. BMC Res Notes 2014;7:316. [CrossRef] [PubMed]

18. Schmeling H, Minden K, Foeldvari I, Ganser G, Hospach T, Horneff G. Efficacy and safety of adalimumab as the first and second biologic agent in juvenile idiopathic arthritis: the German Biologics JIA Registry. Arthritis Rheumatol 2014;66(9):2580-9. [CrossRef] [PubMed]

19. Cecchin V, Zannin ME, Ferrari D, Pontikaki I, Miserocchi E, Paroli MP, et al. Longterm Safety and Efficacy of Adalimumab and Infliximab for Uveitis Associated with Juvenile Idiopathic Arthritis. J Rheumatol 2018;45(8):1167-72. [CrossRef] [PubMed]

20. Neri P, Zucchi M, Allegri P, Lettieri M, Mariotti C, Giovannini A. Adalimumab (Humira): a promising monoclonal anti-tumor necrosis factor alpha in ophthalmology. Int Ophthalmol 2011;31(2):165-73. [CrossRef] [PubMed]

21. Tynjala P, Lindahl P, Honkanen V, Lahdenne $P$, Kotaniemi K. Infliximab and etanercept in the treatment of chronic uveitis associated with refractory juvenile idiopathic arthritis. Ann Rheum Dis 2007; 66(4):548-50. [CrossRef] [PubMed]

22. Schmeling $H$, Horneff $G$. Etanercept and uveitis in patients with juvenile idiopathic arthritis. Rheumatology 2005;44(8):1008-11. [CrossRef] [PubMed]

23. Saurenmann RK, Levin AV, Feldman BM, Rose JB, Laxer RM, Schneider R, et al. Prevalence, risk factors, and outcome of uveitis in juvenile idiopathic arthritis: a long-term followup study. Arthritis Rheum 2007; 56(2):647-57. [CrossRef] [PubMed]
24. Saurenmann RK, Levin AV, Feldman BM, Laxer RM, Schneider R, Silverman ED. Risk of new-onset uveitis in patients with juvenile idiopathic arthritis treated with anti-TNFalpha agents. J Pediatr 2006; 149(6): 833-6. [CrossRef] [PubMed]

25. Rosenberg KD, Feuer WJ, Davis JL. Ocular complications of pediatric uveitis. Ophthalmology 2004; 111(12):2299-306. [CrossRef] [PubMed]

26. Gregory AC, Kempen JH, Daniel E, Kacmaz RO, Foster CS, Jabs DA, et al. Risk factors for loss of visual acuity among patients with uveitis associated with juvenile idiopathic arthritis: the Systemic Immunosuppressive Therapy for Eye Diseases Study. Ophthalmology 2013;120(1):186-92. [CrossRef] [PubMed]

27. Abu Samra K, Maghsoudlou A, Roohipoor R, ValdesNavarro M, Lee S, Foster CS. Current Treatment Modalities of JIA-associated Uveitis and its Complications: Literature Review. Ocul Immunol Inflamm 2016;24(4):431-9. [CrossRef] [PubMed]

28. Sen ES, Ramanan AV. Juvenile idiopathic arthritisassociated uveitis. Clin Immunol 2020;211:108322. [CrossRef] [PubMed]

29. Gueudry J, Touhami S, Quartier P, Bodaghi B. Therapeutic advances in juvenile idiopathic arthritis associated uveitis. Curr Opin Ophthalmol 2019; 30(3):179-86. [CrossRef] [PubMed]

30. Heiligenhaus A, Minden $K$, Tappeiner $C$, Baus $H$, Bertram B, Deuter $C$, et al. Update of the evidence based, interdisciplinary guideline for anti-inflammatory treatment of uveitis associated with juvenile idiopathic arthritis. Semin Arthritis Rheum 2019;49(1):43-55. [CrossRef] [PubMed]

31. Tynjala $\mathrm{P}$, Kotaniemi K, Lindahl P, Latva K, Aalto K, Honkanen V, et al. Adalimumab in juvenile idiopathic arthritis-associated chronic anterior uveitis. Rheumatology 2008;47(3):339-44. [CrossRef] [PubMed]

32. Sen ES, Sharma S, Hinchcliffe A, Dick AD, Ramanan AV. Use of adalimumab in refractory non-infectious childhood chronic uveitis: efficacy in ocular disease - a case cohort interventional study. Rheumatology 2012; 51(12):2199-203. [CrossRef] [PubMed]

33. Ramanan AV, Dick AD, Jones AP, McKay A, Williamson $\mathrm{PR}$, Compeyrot-Lacassagne $\mathrm{S}$, et al. Adalimumab plus Methotrexate for Uveitis in Juvenile Idiopathic Arthritis. N Engl J Med 2017;376(17):1637-46. [CrossRef] [PubMed]

34. Lovell DJ, Ruperto N, Goodman S, Reiff A, Jung L, Jarosova $\mathrm{K}$, et al. Adalimumab with or without methotrexate in juvenile rheumatoid arthritis. $\mathrm{N}$ Engl J Med 2008;359(8):810-20. [CrossRef] [PubMed]

35. Lazarević D, Nikolić I, Ratković-Janković M, Vojinović J. Outcome of Juvenile Idiopathic Arthritis Associated Uveitis in Two Disease Subtypes. Arch Rheumatol, 2017.32(1):26-31. [CrossRef] [PubMed]

36. Ramanan AV, Dick AD, Benton $D$, CompeyrotLacassagne $S$, Dawoud D, Hardwick $B$, et al. A randomised controlled trial of the clinical effectiveness, safety and cost-effectiveness of adalimumab in combination with methotrexate for the treatment of juvenile idiopathic arthritis associated uveitis. Trials 2014;15:14. [CrossRef] [PubMed]

37. Quartier P, Baptiste A, Despert V, Allain-Launay $E_{1}$ Koné-Paut I, Belot A, et al. ADJUVITE: a double-blind, randomised, placebo-controlled trial of adalimumab in early onset, chronic, juvenile idiopathic arthritisassociated anterior uveitis. Ann Rheum Dis 2018; 77(7):1003-11. [CrossRef] [PubMed]

38. Angeles-Han ST, Lo MS, Henderson LA, Lerman MA, Abramson L, Cooper AM, et al. Childhood Arthritis and Rheumatology Research Alliance Consensus Treatment Plans for Juvenile Idiopathic Arthritis-Associated 
and Idiopathic Chronic Anterior Uveitis. Arthritis Care Res 2019;71(4):482-91. [CrossRef] [PubMed]

39. Gamalero L, Simonini G, Ferrara G, Polizzi S, Giani T, Cimaz R. Evidence-Based Treatment for Uveitis. Isr Med Assoc ] 2019;21(7):475-9. [PubMed]

40. Maccora I, Sen ES, Ramanan AV. Update on noninfectious uveitis in children and its treatment. Curr Opin Rheumatol 2020;32(5):395-402. [CrossRef] [PubMed]

41. Cann M, Ramanan AV, Crawford A, Dick AD, Clarke SLN, Rashed F, et al. Outcomes of non-infectious Paediatric uveitis in the era of biologic therapy. Pediatr Rheumatol Online J 2018;16(1):51.

[CrossRef] [PubMed]

42. Birolo $C$, Zannin ME, Arsenyeva S, Cimaz R, Miserocchi E, Dubko $M$, et al. Comparable Efficacy of Abatacept Used as First-line or Second-line Biological Agent for Severe Juvenile Idiopathic Arthritis-related Uveitis. J Rheumatol 2016;43(11):2068-73. [CrossRef] [PubMed]

43. Acharya NR, Patel S, Homayounfar G, Enanoria WTA, Shakoor A, Chakrabarti A, et al. Relapse of Juvenile
Idiopathic Arthritis-Associated Uveitis after Discontinuation of Immunomodulatory Therapy. Ocul Immunol Inflamm 2019;27(4):686-92.

[CrossRef] [PubMed]

44. Horton S, Jones AP, Guly CM, Hardwick B, Beresford MW, Lee RW, et al. Adalimumab in Juvenile Idiopathic Arthritis-Associated Uveitis: 5-Year Follow-up of the Bristol Participants of the SYCAMORE Trial. Am J Ophthalmol 2019;207:170-4. [CrossRef] [PubMed]

45. Castiblanco C, Meese H, Foster CS. Treatment of pediatric uveitis with adalimumab: the MERSI experience. J AAPOS 2016;20(2):145-7. [CrossRef] [PubMed]

46. Acharya NR, Ebert CD, Kelly NK, Porco TC, Ramanan AV, Arnold BF. Discontinuing adalimumab in patients with controlled juvenile idiopathic arthritis-associated uveitis (ADJUST-Adalimumab in Juvenile Idiopathic Arthritis-associated Uveitis Stopping Trial): study protocol for a randomised controlled trial. Trials 2020; 21(1):887. [CrossRef] [PubMed] 


\title{
DUGOTRAJNA EFIKASNOST I BEZBEDNOST PRIMENE ADALIMUMABA U LEČENJU JUVENILNOG IDIOPATSKOG ARTRITISA (JIA) SA UVEITISOM
}

\author{
Dragana Lazarević1,2, Marija Ratković Janković2, Milica Jakovljević2, Jelena Vojinović1,2 \\ ${ }^{1}$ Univerzitet u Nišu, Medicinski fakultet, Niš, Srbija \\ ${ }^{2}$ Univerzitetski klinički centar Niš, Klinika za dečije interne bolesti, Odeljenje dečije reumatologije, Niš, Srbija
}

Kontakt: Dragana Lazarević

Bulevar dr Zorana Đinđića 48, 18000 Niš, Srbija

E-mail: lazarevic.gaga@gmail.com

Poslednjih godina, primena inhibitora tumor nekrozis faktor $\alpha$ (TNF- $\alpha$ ) pokazala je odličnu kontrolu inflamacije prednjeg očnog segmenta kod bolesnika sa juvenilnim idiopatskim artritisom (JIA) sa uveitisom. Retrospektivnom analizom želeli smo da procenimo dugoročnu terapijsku efikasnost i bezbednost primene adalimumaba kod 19 bolesnika sa JIA sa uveitisom, podaci o kojima su preuzeti iz našeg biološkog registra, koji prethodno nisu lečeni biološkim lekom. Prikupljani su demografski podaci i uzorkovana je krv u određenim vremenskim intervalima. Procena aktivnosti upale prednjeg očnog segmenta vršena je biomikroskopskim pregledom. Praćena je pojava ozbiljnih neželjenih efekata.

Naš biološki registar obuhvatio je desetogodišnju analizu podataka 11 (57,90\%) bolesnika ženskog pola, sa dijagnozom oligo i proširenog oligoartikularnog JIA sa uveitisom, dok je $8(42,10 \%)$ bolesnika bilo muškog pola sa dijagnozom artritisa sa entezitisom (ERA) i uveitisom. Adalimumab je bio prvi biološki lek kojim je započeto lečenje bolesnika sa JIA sa aktivnim uveitisom, koji nisu odgovorili na standardni terapijski algoritam. Tokom desetogodišnjeg perioda praćenja, dok su bolesnici lečeni adalimumabom i metotreksatom, nije bilo novih relapsa uveitisa. Svi naši bolesnici nakon uvođenja adalimumaba bili su u mogućnosti da postepeno redukuju i obustave primenu tipičnih kortikosteroida. 36,84\% bolesnika bilo je u mogućnosti da prekine primenu biološke terapije 36 meseci nakon počeka primene adalimumaba. Samo kod dva bolesnika zabeležan je relaps uveitisa 3 meseca nakon prestanka primene adalimumaba. 31,58\% bolesnika ispoljilo je blage neželjene reakcije, dok ozbiljne neželjene reakcije nisu zabeležene.

Tokom desetogodišnjeg perioda praćenja, adalimumab je pokazao dobru terapijsku efikasnost i bezbednost u lečenju bolesnika sa JIA sa uveitisom.

Acta Medica Medianae 2021;60(3):30-36.

Ključne reči: juvenilni idiopatski artritis, uveitis, adalimumab 